\title{
UTOPIA EM PESSOA
}

Carmen Sílvia Ribeiro é graduada em Produção Textual na Pontifícia Universidade Católica do Rio de Janeiro e aluna extraordinária de mestrado em Literatura, Cultura e Contemporaneidade na PUC-RIO - ribeiro140@ gmail.com.

\author{
Ai... que silêncio imortal, \\ Nesse lugar, pretensiosamente Olimpo! \\ Esse lugar sem tempo/espaço, \\ Que eu, uma reles mortal, \\ Vasculho em mergulhos inconscientes... \\ Em busca de um portal que me leve a Zeus.
}

Que tola que sou... como ouso tal pretensão.

Zeus, o inatingível deus, que todos devem temer,

Até mesmo os inocentes e puros d'alma não estão incólumes

Às intervenções catastróficas de Zeus.

Quem me dera eu pudesse ser ao menos uma semideusa

Para ir além desse silêncio enlouquecedor que emudece minh 'alma,

Logo ela que quer voar

E tem que permanecer tolhida nos limites da humanidade.

Que lugar é esse?

Que sou, conforme estou...

Que os poderes, apenas humanos,

Jamais poderão ultrapassar...

Ai... o poeta finge deveras à Esfinge 
Que chega a doer-se de tanto fingir! 